\title{
THE THEORY OF MONEY IN THE LAW OF COMMERCIAL INSTRUMENTS
}

\author{
Herman Oliphant \\ University of Chicago Law School
}

The term, commercial instruments, is used in this discussion to include all bills of exchange, promissory notes and other like instruments falling within the custom of merchants. It is purposed to examine the decisions as to the commercial status of certain types of bills and notes. Their importance is apparent when there are recalled some of the special attributes of commercial instruments. At least historically, only a commercial instrument could become transferable so as to vest legal title in a transferee if words of negotiability were added. ${ }^{1}$ Only such an instrument may be so transferred as to free its holder from various defences. Commercial instruments are subject to special rules of pleading and proof. To them the whole law of diligence in presentment and notice of dishonor applies. They are cften the subject of special legislative provisions concerning limitation of actions, taxation and the likẹ.

The prime purpose of this discussion is to consider what is meant by money in the law of bills and notes. It is convenient and desirable to consider also certain closely related questions. Since the Negotiable Instruments Law has been adopted in all of the states except Georgia, it will be well to clear the ground of kindred questions which will be excluded from the discussion by reference to the pertinent section of that act. Section I provides that,

"An instrument to be negotiable must . . contain an unconditional promise or order to pay a sum certain in money."

This discussion will be limited to a consideration of the meaning of, "to pay" and, "in money." The following distinct questions arising under the provision just quoted will, therefore, be excluded:

(a) When does an instrument contain an order or promise within the meaning of this section? One of the questions to be considered here is raised by granting that a particular instrument contains an order or a promise to do some act and then asking whether the act ordered or promised is the act of paying.

(b) Is the order or promise unconditional? Excluding this question excludes also tine collateral question as to what is meant by an order or promise to pay out of a particular fund which is covered by the provisions of section 3 of the Negotiable Instruments Law.

(c) Is the sum ordered to be paid or promised certain?

${ }^{1}$ Whether this distinction has more than historical importance is not considered. 
THE MEANING OF "TO PAY"

The question as to the meaning of "to pay" as here limited is quite narrow. Accordingly, but few cases have involved it and they may be disposed of briefly. They are cases where the instruments in question contain forms of such verbs as "to account," "to credit," and "to settle" instead of "to pay" following the words of promise or order. Are such instruments commercial?

In an instrument reading, "I promise to account to $P$ for $\$ 100, "$ or " . . . to be accountable . . . ," the usual meaning of the infinitive is, "We will state accounts." If there is no sufficient reason for giving the words any meaning other than their usual one, such an order or promise is not a bill or note ${ }^{2}$ since the promise may be performed without its maker handing over any money. He may merely credit the promisee with the amount named. If words of negotiability are added, it is otherwise. ${ }^{3}$ As was pointed out in the first case on the subject, ${ }^{4}$ there is no probability of any and all possible transferees of the instrument being indebted to the maker or drawee so as to make a statement of accounts possible. It is proper to conclude that in such a case the expression is used in an unusual sense, viz., "to pay." The same rule is properly applied where the expression used is "to settle." Where, however, there is an order or promise "to credit," it would seem that the words should be given their usual meaning, although words of negotiability are present. While it may be improbable that any and all transferees will be indebted to the drawee or maker so as to make a statement of accounts or a settlement possible, it will be possible for the drawee or maker to enter a credit in favor of any transferee whether such credit is in payment of a debt or not. Since it does not appear from the face of such an instrument that money is necessarily to be handed over, it is not a commercial instrument." Adding to an order to credit $\mathrm{P}$ or order the words "in cash" makes the order a bill of exchange $e^{7}$ as the obvious meaning of "to credit" is now the unusual one, to pay. It is believed the same is the proper construction of the language although words of negotiability are not present. ${ }^{8}$

Considering the number of cases involving it, the question is not important, ${ }^{\circ}$ but, in studying the cases on whether or not an instru-

\footnotetext{
Horne v. Redfearn (1838) 4 New Cas. 438; White v. North (1849) 3 Exch. 689; Carey v. Eccleston (1834) I Cr. \& D. Abr. Cas. 6; Pirie v. Smith (1833) I Ross Lead. Cas. 56, XI Sess. Cas. 473.

"Morris v. Lee (I725) I Strange, 629. 'Ibid.

- Barker v. Seaman (1875) 61 N. Y. 648.

'Woolley v. Sergeant (1826, N. J.) 3 Halst. L. 262.

'Ellison v. Collingridge (185a) 9 C. B. 570; Allen v. Fire \& Life Assurance Co. $(1850)$ 9 C. B. 574.

'See Regina v. Gilchrist (I84I) Car. \& M. 224.

- No other cases dealing with this question have been found.
} 
ment contains a promise or order, it is helpful to distinguish the two questions, which is not commonly done.

\section{WHAT IS MONEY?}

Coming now to the main question to be considered, it may be stated thus: Is an instrument rendered non-commercial by the fact that, by its terms, the thing to be handed over in payment of it is not legal tender although it is a medium passing current in exchange and is considered to be money by the business world? Examples are bills and notes payable in gold or silver certificates, national bank notes, or federal reserve notes. Are they payable in money?

In considering the question, what is money for the purposes of commercial paper, there can be left out of view instruments payable in property in no sense approximating money such as "in good merchantable whiskey." ${ }^{10}$ These instruments were not and are not within the custom of merchants as they are generally acceptable, and hence useful, only in communities but one step removed from a barter economy. ${ }^{11}$ There will be considered later instruments payable in property which in particular communities is used as a medium of exchange.

An examination of the cases ${ }^{12}$ shows that most of the courts have adopted the theory that nothing is money for the purposes of negotiable instruments unless it is legal tender although, by what is in most cases an unwarrantable construction of the language used, many of the courts taking this view reach the practical result that instruments expressed to be payable in de facto money are none the less commercial instruments. Most of the recent text-writers also take the view that money is confined to what is tenderable for debt. Some are quoted in the foot note. ${ }^{13}$ Few of them discuss the question

${ }^{10}$ Rhodes $v$. Lindley (1827) 3 Oh. $5 \mathrm{I}$ and cases collected in $8 \mathrm{C}$. J. 130.

in The financial structure of society during the early part of the last century in some of the newer states led to statutes giving various attributes of commercial paper to instruments payable in property generally. Alabama: Toulmin's Digest, 69, act approved 1812; Georgia: Code, sec. 4270, act approved I799; Illinois : Rev. St. I845, ch. 63, act approved 1845 ; Iowa: Rev. St. I843, ch. 106, act approved I843; Mississippi: Hutchinson's Code, 640, act approved I822; Missouri: Rev. St. 1845 , ch. 21, act approved 1835 . The Illinois statute is still in force as to notes payable in things other than money since, by sec. I, the negotiable instruments law as adopted in Illinois is limited to instruments payable in money. The negotiable instrument law not having been adopted in Georgia, the statute of $I 799$ is still in force.

12 See notes $21-24$, infra.

18 "A bill must be payable in money, i. e., in what is a legal tender in payment of debts at the place of payment." 2 Ames, Cases on Bills and Notes (1894) 828.

"The bill cannot be made payable in the money of any country whatever. It must be payable in legal tender of the place where it is made payable. . . . 
critically. It is noteworthy that no such idea is to be found in the early writers on bills and notes.

Using the word, money, in the broadest sense, the following attributes of the things included thereunder may be distinguished:

(I) By legislation some kinds of money are made legal tender of payment of some or all kinds of debt. ${ }^{14}$ The effects of this attribute are that, if such money is tendered by a debtor in strict compliance with all the numerous and exacting requirements of a proper tender and the tender is refused, interest as an element of damages ceases to accumulate, the creditor may not thereafter in an action to collect the debt recover his costs, parties secondarily liable are discharged and securities on property are lost. ${ }^{15}$

(2) Not by governmental fiat but because of the necessities of trade there are in existence common media of exchange, which are sometimes and in some places quite conventional and at other times and in other places quite the reverse. Gold dust in mining communi-

but in so far as they [statements by Chitty and Story] or the cases founded upon them, or upon which they are founded, embody the proposition that a good promissory note can be made, the obligation of which can be discharged by the tender of that which is not legal tender at the place of paymient, they are unsound in principle and in conflict with the requirement that the note should be payable in money." Russell, Bills, 56.

"Bills and notes, being representatives of money, must be payable in money. 'Money', within this rule, means whatever may be used as legal tender for payment of debts at the place where the bill or note is payable." Norton, Bills and Notes (4th ed. I9I4) 6r. "By 'money' is meant, in strictness, that which by law is tenderable for debt, that is, assuming that no provision is made for payment in anything else. If the instrument is not payable in money, or in what the courts judicially know to be equivalent to money, it is not an instrument of the law merchant. . . . The difficulty lies in what is to be accepted as judicially known to be equivalent to money. It is hardly safe to call anything the equivalent of money on the ground that it passes as such at certain places; . . . Nor is it safe to treat currency, unless it is the currency of the nation, as equivalent to money; for currency is apt to fluctuate, that is, to fall from its face value. The most, it seems, that the law should allow would be a promise to pay in current money of a 'particular kind.'" Bigelow, Bills, Notes and Cheques (2d ed. r900) 27,28 . It is not entirely clear just what position this quotation represents.

${ }^{14}$ In the United States legal tender is limited to: (a) gold coin and the silver dollar for any amount; (b) the subsidiary silver coins for not over ten dollars; (c) the minor coins for not over twenty-five cents; (d) United States notes for any amount and for all debts except duties on imports and interest on the public debt. U. S. Comp. St. secs. 6571-6575. Federal reserve notes are at most legal tender only to member banks and in payment of taxes, customs and public dues. U. S. Comp. St. sec. 9799. National bank notes and gold and silver certificates are not legal tender. The Vreeland currency was not, and treasury notes are not now, legal tender.

${ }^{25} 38$ Cyc. 162, 163; N. I. L. secs. 120-4. These legal consequences are doctrines of the law antedating legal tender legislation and in application are not conterminous therewith. 
ties, skins among trappers, and the American dollar in parts of Mexico and Canada serve this function as truly as does any form of money anywhere. The utility of a particular thing as a medium of exchange in a given locality is measured by the degree to which it approaches universal acceptability in exchange in the area in question. The test here is how readily receivable it is.

(3) Mensuration of gravity and space is no more convenient and necessary than is the ability to express in common units the power of articles in exchange. Doubly convenient is a value yardstick that is also one of the things exchanged. The practice of having a common denominator of value and of making the medium of exchange serve this purpose also is followed wherever governmental monetary systems prevail and is of incalculable utility.

(4) When men bartered only and did not sell on credit or lend they got just what was due them. When they began to exchange property for tokens they did not, unless the future exchange power of the tokens was constant. Credit necessitates a standard of deferred payments, which some forms of money are with varying success.

(5) The things used for any or all of the foregoing purposes may have and often do have intrinsic value. In early times they usually did, now they less and less frequently do. Many factors, some physical and some psychological, put gold in this class. Money possessing this quality may have a commodity value independent, within limits, of its exchange value or purchasing power.

That these attributes and functions are practically distinguishable is shown by the following considerations. Legal tender is not always current. The price of gold has, at times, driven gold coins out of circulation. It would be awkward but not impossible to make a thing legal tender which was not denominative. ${ }^{18}$ Our "greenbacks," though legal tender, failed to function satisfactorily as a standard of deferred payments and they possess no intrinsic value comparable with their nominal value. The greater part of our medium of exchange is not legal tender and has no intrinsic value. Once gold dust in Alaska and pelts on the Mississippi were generally acceptable in exchanges in which the calculation was done in terms of dollars and cents. Many contend that a system much more desirable than our present one would be a scheme making the standard of deferred payments a group of commodities distinct from the things we use as money in any other sense.

In considering which of the foregoing qualities is definitive of money for the purposes of bills and notes, the choice lies between the first two. There has been no contention whether things not common denominators of value are money. So, too, as to the use of money to fix the obligation of a contract of payment. ${ }^{17}$ Wilson, J., in Gray v. Worden

\footnotetext{
${ }^{18}$ Breckinridge, Legal Tender (1912) 53, 54.

${ }^{17}$ Questions relating to the standard of deferred payments are considered infra.
} 
announced the novel doctrine that a promise to pay a sum in Canada bills which were legal tender at the place of payment was not a note because not payable in money. He said:

"Canada bills . . . are not money or specie. They have no intrinsic value as coin has. They represent only, and are the signs of, value. 'Money itself is a commodity: it is not a sign; it is the thing signified.' "18

The uniqueness of this decision is not likely to be disturbed. ${ }^{10}$

Almost all the questions arising in this field resolve themselves into, whether an instrument, otherwise a bill or note, payable in a thing possessing the attribute of being current and not that of legal tender is payable in money. This question is raised in two ways. The instrument may be expressly payable in such a thing, e. g., "payable in National Bank Notes," "currency," "current funds," "Tennessee money" and the like. Upon the question so raised there was a marked division of opinion in the United States prior to the Negotiable Instruments Law. Some courts took the position that money is not limited to legal tender but includes also the de facto media of exchange, holding both types of instruments good. $^{21}$ More courts, starting with the assumption that money is

${ }^{18}$ (1870) 29 U. C. Q. B. 535.

${ }^{10}$ Of this case Russell says: "For this view of the matter McCullock's Political Economy is cited; but a more appropriate source of authority for the determination of a legal question would be Lord Mansfield who said in Miller v. Race, 1758, I Burr. 452: 'These notes are not like bills of exchange, mere securities or documents for debts, nor are they so esteemed, but are treated as money in the ordinary course and transaction of business by the general sense of mankind, and on payment of them when a receipt is required the receipts are always given as for money and not for securities." Russell op. cit., 54 . But Mr. Russell does not accept Lord Mansfield's definition of money here quoted. See note 13; supra. "The opinion expressed (in Gray v.'Worden) that legal tender notes are not money, however sound in political economy, is unsound in law." 2 Ames, op. cit., 82g. It is unsound in political economy and is neither good law nor good sense. The difference between a silver dollar and a one dollar silver certificate is, indeed, for most practical purposes less important than the difference between a silver dollar and a gold dollar. Within limits, the exchange values of both the silver dollar and the silver certificate are wholly independent of their intrinsic or commodity value while, by definition of standard, the exchange value and commodity value of the gold dollar are the same thing.

${ }^{20}$ Pardee v. Fish (1875) 60 N. Y. 265.

" Cases of instruments in terms payable in what was not legal tender being held good are extremely rare. Pardee $v$. Fish, supra, is such in view of the effect of I2 Stat. L. 709; 13 Stat. L. 484; I4 Stat. L. I46; I5 Stat. L. 6, and Veazie Bank v. Fenno (1869, U. S.) 8 Wall. 533. See also Deason v. Taylor (1876) 53 Miss. 697; cf. Mississippi cases cited in note 23, infra. In the following cases the instruments were expressed to be payable in currency and the like. This was held not to affect their commercial character: 'Swift v. Whittey (I858) 20 III. I44 ("They might, undoubtedly, have been negotiated under our statute, if not by the law merchant); Kupfer $v$. Marc (1862) 28 IIl. 388 (bill 
limited to legal tender, held instruments of the first class not bills or notes, ${ }^{22}$ but differed as to the second class. Some held that the expressions in question, as a matter of construction, mean money; i. e., legal tender, and do not, therefore, destroy the commercial character of the instruments. ${ }^{23}$ Others held that they mean just what they say and the instruments containing them are, in consequence, non-commercial. ${ }^{24}$

of exchange to which that statute does not apply) ; Marc v. Kupfer (1864) 34 III. 286; Wood v. Price (1868) 46 III. 435; Tedford v. Patton (1893) I44 III. 6ri, 33 N. E. IrIg (semble); Insurance Co. v. Allen (1863) Ir Mich. 50r; Phelps v. Town (1866) I4 Mich. 374; Black v. Ward (1873) 27 Mich. I9r; White v. Richmond (1847) I6 Oh. 5; Howe v. Hartness (1860) II Oh. St. 449 (and see Dugan v. Campbell (I823) I Oh. II5 and Citizens Bank v. Brown (1887) 45 Oh. St. 39). Klauber v. Biggerstaff (1879) 47 Wis. 55 I (overruling Ford v. Mitchell (1862) I5 Wis. 334; Platt v. Sauk County Bank (1862) I7 Wis. 222; Lindsey v. McClelland (I864) I8 Wis. 481. Before the Civil War the New York court took the view that currency is money. See its holdings on instruments payable in bank notes cited in note 30 , infra. Distinguish Leiber $v$. Goodrich (1825, N. Y.) 5 Cowan, I86. In one case since it seems to have adopted the legal tender definition. Frank $v$. Wessels (1876) 64 N. Y. 155. Distinguish Ehle v. Chittenango Bank (1862) 24 N. Y. 548. Only in Ohio is it clear that the cases under this group do not proceed on the theory that currency at par is a necessary attribute of money. See particularly the holdings on the related question as to the measure of recovery: Trowbridge $v$. Seaman (1859) 2I Ill. Ior; Chicago Insurance Co. v. Keiron (1862) 27 Ill. 50r ; Chicago Bank v. Birney (1862) 28 Ill. 99; Northern Bank v. Zepp (1862) 28 Ill. 18a; Galena Insurance Co. v. Kupfer (1862) 28 III. 332; Chicago Bank v. Rushmore (I862) 28 IIl. 463

$=2$ But one case of an instrument expressly payable in what was not legal tender being held non-commercial has been found: Lange v. Kohne (1821, S. C.) I McCord, II5; see Gordon v. Parker (1844) Ia Miss. 485; but see Gift v. Hall (1840, Tenn.) I Humph. 480 .

${ }^{23}$ Cases of instruments in which the expressions used were construed to call for legal tender with the result that such instruments were held commercial are: Bull v. Bank of Kasson (1887) 123 U. S. 105, \& Sup. Ct. 62 (not clear that Court proceeded on legal tender theory, see opinion and earlier case of Trebilcock v. Wilson (I871, U. S.) I2 Wall. 687); Lacy v. Halbrook (1842) 4 Ala. 88 (but see Mobile Bank v. Brown (I868) 42 Ala. I08); Milligen v. Security Trust Co. (I9I8, Ind.) II8 N. E. 568 (overruling National Bank v. Ringel) ; Kuhn v. National Bank (1918, Ind.) I19 N. E. I45; Hatch v. Dexter Bank (1900) 94 Me. 348, 47 Atl. 908 (probably based on this theory); Laird $v$. State (1883) 6r Md. 309; Butler v. Paine (1863) 8 Minn. 324; Kirkwood v. Hastings Bank (1894) 40 Neb. 484, 58 N. W. Iar6; Kirkwood v. Exchange Bank (I894) 40 Neb. 497, 58 N. W. II35; Frank v. Wessels (1876) 64 N. Y. 155; see New York cases cited in note 2I, supra. The holder of such an instrument could therefore recover its face value in specie. Burtorn $v$. Brooks (1868) 25 Ark. 215; Graham v. Adams (1843) 5 Ark. 26I; Wilbur v. Greer (I845) 6 Ark. 255; Lampton v. Haggard (1826, Ky.) 3 T. B. Mon. I49; McCord v. Ford, supra, I66 (but see Bainbridge v. Owen (I829, Ky.) 2 J. J. Mar. 463 and the Kentucky cases in note 24, infra); Gift v. Hall (I840, Tenn.) I Humph. 480. See further: Fry v. Dudley (1868) 20 La. Ann. 368; Gordon v. Parker (1844) 10 Miss. 485; Mitchell v. Hewitt (1845) 13 Miss. 361 ; Cockrill v. Kirkpatrick (1846) 9 Mo. 697; Ogden v. Slade (1846) I Tex. I3.

$\because$ In the following cases the expressions were held not to call for legal tender 
Without examining the violence of construction often necessary to reach the result attained by courts holding these expressions to mean legal tender, there will be considered first the origin and then the merits of the doctrine that money is confined to legal tender, which doctrine it is that has driven these courts to such extremes in construction.

The origin of the holding that "money" is limited to legal tender is interesting and sheds considerable light upon the question as to the present validity of the doctrine.

The beginning of this doctrine is Harrison's Case. ${ }^{25}$ An accountant to the London Assurance Company added the digit 3 to a credit entry in the company's bank book so that the entry read, "I777, June I6, Bank Notes C. $£$. 3210." He was indicted under 2 Geo, 2 ch. 25 and 31 Geo. 2 ch. 22, f. 78 for forging a receipt for money. The court allowed the objection that bank bills were not money or goods within the intent of these statutes since they were confined to money or goods, while in 7 Geo. 2, bills, notes, etc. are particularly mentioned. In Rex $v$. Wilcox, ${ }^{26}$ the prisoner was pardoned following a conviction for forgery of a promissory note "to pay the bearer on demand one guinea in cash or Bank of England Notes." No other report of this case has been found. This one is most unsatisfactory. Both of these being criminal cases and the penalty being death, they are a most unsatisfactory basis for a rule in commercial law. ${ }^{27}$ But they were so used in two English cases $^{28}$ in the early part of the rgth century

and the instruments were held not to be bills or notes: Mobile Bank v. Brown (1868) 42 Ala. I08; National Bank v. Ringel (1875) 5I Ind. 393 (overruled and see Drake v. Markle (1863) ar Ind. 433 and cf. Krieg v. Palmer Bank (IgII) 5 I Ind. App. 34, 95 N. E. 613); Rindskoff v. Barett (1860) II Iowa, 172; Pilmer v. State Bank (1864) I6 Iowa, 321; Huse v. Hamblin (1870) 29 Iowa, 501 (but see Haddock v. Wood ( 1877 ) 46 Iowa, 433 and American Emigrant Co. v. Clark (1878) 47 Iowa, 671 wherein the court found it necessary to relax its rule by allowing it to be controlled by parol evidence and $c f$. Rindskoff $v$. Barett (1862) 14 Iowa, IaI); Johnson v. Henderson (1877) 76 N. C. 227 (but see Johnson v. Miller (1877) 76 N. C. 439); Wright v. Hart (1863) $44 \mathrm{~Pa} .454$ (see comment on this case in Black v. Ward, supra); Loudon Society $v$. Hagerstown Bank (1860) $36 \mathrm{~Pa} .498$ (semble); Texas Land Co. v. Carroll (I885) 63 Tex. 48 (cf. Wright v. Morgan (1896, Tex. Civ. App.) 37 S. W. 627 and $M c$ Cormick v. Kampman (1908, Tex. Civ. App.) rog S. W. 492). Blood v. Northrup (1862) I Kan. 28 is to be distinguished. Recovery by a holder of such an instrument was, accordingly, limited to the face less depreciation. Clambers v. George (1824, Ky.) 5 Litt. 335 (explained in McCord v. Ford); Conwell v. Pumphrey (1857) 9 Ind. I35; Wharton v. Morris (1785, Pa.) I Dall. 124; Coffin v. Hill (I870, Tenn.) I Heisk. 385; Taylor v. Neblett (1871, Tenn.) 4 Heisk. 49r; Williams v. Arnis (1867) 30 Tex. 37.

${ }^{25}$ (1777) 2 East, Pleas of the Crown (1806) 927.

"( 1808 ) Bayely, Bills (2d A.m. ed. 1836) 10.

${ }^{27}$ See a like holding under anothet criminal statute, Rex $v$. Hill (I8II) Russ. \& R. I90.

${ }^{23}$ Exx parte Imerson (1815, Eng. Bank.) 2 Rose B. C. 225 ; Ex parte Davidson (I8I7) Buck B. C. 3 I. 
in the face of the fact that Bank of England notes were then considered as money in all ordinary business transactions though they were not legal tender. ${ }^{2 \theta}$ None of these cases put the matter expressly on the ground that absence of legal tenderability is the deciding feature.

In the United States the history of this subject prior to the Civil War is largely a reflection of the parallel history of our monetary system during this period. It is characterized principally by the struggle between those favoring state banks with power of issue and those favoring a federal bank or banks with like powers, which contest continued of uncertain event until the Civil War. Among other ways, this dispute appeared in the cases in the question as to the status of the circulating notes of state banks, one aspect of it being whether an instrument payable in bank notes was commercial.

The cases on this question scarcely admit of arrangement. ${ }^{30}$ There

${ }^{9}$ Grigby v. Oakes (180r, Eng. C. P.) 2 Bos, \& P. 526.

${ }^{30}$ Classifying the cases by jurisdictions, those holding instruments payable in bank notes commercial are: Besanson v. Shirley (1848) I7 Miss. 457 (statutory); Keith v. Jones (1812, N. Y.) 9 Johns. I2a; Judah v. Harris (I821, N. Y.) I9 Johns. 144; Shetland v. Creigh (I846) 15 Oh. II8; This holding was limited to bank notes that were current: Bonnell v. Covington (I843) 8 Miss. 322; Little v. Phenix Bank (I842, N. Y.) 2 Hill, 425 ; Shamokin Bank v. Street (1864) I6 Oh. St. I. That the holder may recover the face at specie value was held in Morris $v$. Edwards (1823) I Oh. I89 and Fleming $v$. Nall (1846) I Tex. 246. Cases holding such instruments to be non-commercial are:Fry v. Rousseaw (I842, C. C. 7th) 3 McLean, I06, Fed. Cas. No. 514I ; Irvine v. Lowry (I840, U. S.) 14 Pet. 293; Carlisle v. Davis (1844) 7 Ala. 42 (but cf. Carter v. Penn (1842) 4 Ala. 140); Hawkins v. Watkins (1843) 5 Ark. 48r; Breckinridge v. Ralls (I827, Ky.) 4 T. B. Mon. 533 (and cf. Stucker v. Miller (1824, Ky.) 5 Litt. 235); Jones $v$. Fales (I808) 4 Mass. 245 (holding limited to non-current notes); Farwell v. Kennett (1842) 7 Mo. 595; State v. Corpening (1849, N. C.) ro Ired. 58; Warren v. Brown (187a) 64 N. C. 38r (and cf. Patton v. Hunt (1870) 64 N. C. 163); McCormick v. Trotter (I823, Pa.) 1o Serg. and R. 94; Gray v. Donohoe (1835, Pa.) 4 Watts 40a; Gamble v. Hatton (Tenn.) Peck. 130; Kirkpatrick v. McCullough (I842, Tenn.) 3 Humph. I7I; Whileman v. Childress (1845, Tenn.) 6 Humph. 30I ; Simpson v. Moulden (I866, Tenn.) 3 Coldw. 429 (cf. McDowell v. Keller (1867, Tenn.) 4 Colo. 258 and Childress v. Stuart (I823, Tenn.) Peck. 276); Collins v. Lincoln (1839) II Vt. 268. In Wolfe v. Tyler (1870, Tenn.) I Heisk. $3^{13}, 3^{16}$, it is said, "The principle . . . that a note payable in current bank notes is not a note for money and, therefore, not negotiable rests upon a highly technical distinction." In Butler v. Pdine (1863) 8 Minn. 324 the cases are classified thus: Whenever the instrument was payable within the state where litigated, the courts took judicial notice whether the currency was at par. If so, the instrument was held good. Whenever the instrument was payable in the currency of another state and without the state where litigated, no such notice could be taken and the instrument was held noncommercial. Jurisdictions holding an instrument payable in bank notes to be non-commercial generally held that debt would not lie wherever and whenever bank notes were seriously depreciated. Otherwise the holder could have recovered a judgment for the face which could be satisfied only by the payment of specie. Jackson v. Waddill (1828, Ala.) I Stew. 579; Young v. Scott (1843) 5 Ala. 475; Dillard v. Evans (1842) 4 Ark. 175; Mitchell v. Walker 
were conflicts of judicial opinion among the various" states and often in the cases of a single state. Of the Kentucky cases, McBride, J., said in Cockrill v. Kirkpatrick:

"Whilst the banks in Kentucky redeemed their notes in gold and silver, the expressions [payable in bank notes and the like] amounted to nothing, they were imperative; but so soon as the banks suspended, then the parties were presumed to contract for the irredeemable paper currency of the State. Our bank, however, has not been forced into a position so humiliating, and our courts have not yet been driven to such extremities in endeavoring to satisfy the exigencies of the public on the one hand, and a faithful discharge of their duty on the other."si

Some of the factors operative to produce this confusion were: varying inclinations on the political aspects of the question, different degrees of depreciation from state to state, unlike statutory and administrative support given bank currency in the different states, and the varying supply of other media of exchange in different areas. In turn, all of these factors varied from decade to decade. Little wonder that the decisions were quite as chaotic as was the nation's currency during much of this period. The notion, long held, that only coin could be made legal tender, under the constitution, confused the issue considerably.

For the purpose in hand it is useful to recognize that these cases are of doubtful value in determining the rule proper to be applied to-day. The conditions then are not those of the present. True the legal tender device was used little in the attempts to cure the evils of an unsound currency. ${ }^{32}$ Nor would its use have helped much, if any. The basic difficulties were unregulated issue and uncertain redemption.

Since the Civil War the drift in the cases shows an increasing recognition of the fact that the basic test of money of any kind is its ability adequately to function as a medium of trade. The things causing this change of view have been the introduction of United States legal tender notes and the parity of all of our currency. So long as the rule applied is one based on unsound theory and is inflexible, as the legal tender rule is, the inconvenience of a changing rule will not be avoided.

Returning to the question as to the merits of limiting money to legal tender, the rule ignores the history of bills and notes, is unsound on principle and is inconvenient in practice.

(1842) 4 Ark. I45; Campbell v. Weister (I822, Ky.) I Litt. 30; Deberry v. Darnell (1830, Tenn.) 5 Yerg. 45I; Hicklin v. Tucker (1830, Tenn.) 2 Yerg. 448. And see Lackey v. Miller (I866) 6I N. C. 26; Hopson v. Fountain (1844, Tenn.) 5 Humph. 140. Cf. Paup v. Drew (1850, U. S.) r9 How. 218. Contra is Searcy v. Vance (1827, Tenn.) Mart. \& Y. 225. This rule did not necessarily mean that the instrument was therefore not commercial, but this distinction was one easily lost sight of.

"1846) 9 Mo. 697, 702 .

a Paper currency was at times made legal tender to public creditors only. 
The law of commercial paper is but a part of the law merchant "applied under its proper rules to the business of trade and commerce"33 which larger body of law is international in its origin. "These rules are not conceived to be purely English law; they are, we may say a ius gentium known to merchants throughout Christendom." ${ }^{34}$ True, under the heavy hands of many of the judges prior to Lord Mansfield, the law merchant was provincialized to a lamentable degree, but, by his research among its sources and by information got first hand from merchants, he restored to this body of law much of its ancient and convenient aspect of an international mercantile code. Legal tender laws, on the other hand, are only national in their scope. The law merchant in its growth and operation transcended national boundaries and was as international as the trade it regulated and facilitated.

The presence of the legal tender attribute of money ordinarily presupposes a governmental monetary system. The contention that this attribute of money is definitive must face the fact that, in the history of trade, a public money system is of comparatively late origin while the device of legal tender is a still more recent invention. At some times and in some places, trade has existed without the former and has flourished without the latter. While legal tender has proved very useful, ${ }^{35}$ it is not, and never was, essential to trade. It has contributed far less to the stability and consequent utility of money than has any of the policies of regulated coinage and issue, strict standards of fineness in coinage, and ample means for the redemption of paper currency.

Why are bills and notes required to be payable in money? Admittedly to increase their acceptability in the conduct of trade, to make them useful devices of exchange. If the prospective transferee of a bill or note can see that he will get out of it a universally acceptable commodity, that is enough to effectuate the purpose of the requirement. He will get that if the instrument is payable in things that pass current as money whether they do or do not happen to possess the more or less artificial attribute of tenderability.

It is open to a layman to insist that things legal tender are not always money for the purpose in hand because legal tender money has often failed to pass current. There is no contention that it is open to our courts of law to take this position. It is correct to say, as all courts would, that, if an instrument is payable in legal tender, it is clearly good. ${ }^{38}$ Courts are bound by legal tender laws and must accept

\footnotetext{
${ }^{33}$ Hale, History of the Common Law (3d ed. 1739) 25.

${ }^{34}$ I Pollock and Maitland, History of English Laze (2d ed. I899) 467.

${ }^{3}$ Too often it has been used as a high-handed revenue measure to the detriment of trade. Possibly the most startling example of this is the one from China related by Marco Polo in describing the remarkable device by which the Great Kaan got "more treasure than all the Kings of the World."

${ }^{30}$ Woodruff v. Mississippi (1895) I62 U. S. 29I, 16 Sup Ct. 820.
} 
legal tender as an affirmative test, but there is no such necessity of making it the negative test as well.

To say that nothing is money unless it is legal tender makes an instrument payable in silver half-dollars non-commercial if it happens to exceed ten dollars. Is the theory of bills and notes such that a repeal of our legal tender laws would leave us without negotiable instruments?

The narrower definition of money is inconvenient in practice. When, as now, the greater part of our circulating medium is not legal tender, it is a hardship to prohibit business men, at the peril of having their paper declared non-commercial, to make their paper payable in what they and everybody else are perfectly willing, and practically compelled, to take as money. Are banks to be unable to protect themselves by making their paper payable in current funds if the whole business community be willing that they should? Our present money policy and our whole national financial structure are predominantly founded upon the fact of currency rather than tenderability. The law of bills and notes should square itself to this policy.

The broader definition of money contended for here does not involve the result that a bill or note payable in negotiable bills or notes would be a commercial instrument. ${ }^{37}$ It is true that negotiable bills and notes serve as media of exchange in a broad sense. But the dividing line is to be drawn where convenience dictates. The distinction is a practical one and is quite obvious. Thus a bank note is not a mere chose in action and may, accordingly, be levied on by an execution. Other examples are to be found in the foot note..$^{38}$ Lord Mansfield's statement of this distinction, made in another connection, is scarcely to be improved:

"But the whole fallacy of the argument turns upon comparing banknotes to what they do not resemble, and what they ought not to be compared to, viz. to goods, or to securities, or documents for debts. Now they are not goods, not securities, nor documents for debts, nor are so esteemed: but are treated as money, as cash, in the ordinary course and transaction of business, by the general consent of mankind; which gives them the credit and currency of money, to all intents and purposes. They are as much money, as guineas themselves are; or any other current coin, that is used in common payments, as money

\footnotetext{
${ }^{3}$ That they are not: Hasbrook v. Palmer (1839, C. C. 7th) 2 McLean, ro, Fed. Cas. No. 6188; The Lykus (1888, S. D. N. Y.) 36 Fed. 919; January v. Henry (1825, Ky.) 3 T. B. Mon. 8; First National Bank v. Slette (1897) 67 Minn. 425, 69 N. W. I148; Chandler v. Calvert (IgoI) 87 Mo. App. 368; Hamburg Bank v. Johnson (1846, S. C.) 3 Rich. 42; First National Bank v. Greenville Bank (1892) 84 Tex. 40, I9 S. W. 334

${ }^{88}$ Handy v. Dobbin (1815, N. Y.) I2 Johns. 219 and see further Pohlmanv. Pohlman (1912) I5a Ky. 679, 150 S. W. 829; Anderson Carriage Co. v. Bartley (I907) 102 Me. 492, 67 At1. 567; Michigan Cent. Ry. v. Harsha (1904, C. C. A. 6th) ${ }_{34}$ Fed. 217, 22r ; State v. Mispagle (1907) 207 Mo. 557, 106 S. W. 513. Cf. Johrson v. Tabor (rgrI) Ior Miss. 78,57 So. 365 .
} 
or cash. They . - . are never considered as securities for money, but as money itself. . . . On payment of them, whenever a receipt is required, the receipts are always given as for money, not as for securities."

The rule contended for that anything passing current as cash is money, does not, accordingly, include negotiable bills and notes ${ }^{40}$ within the category, money. Further qualification is necessary. A particular thing may serve as a medium of exchange, passing current as cash, in such a limited area or for so short a time that it should not be denominated money for the purposes of bills and notes.1 But anything which for a substantial period of time and throughout any important commercial community is, by general consent, used and treated in common payments as cash in the ordinary course and transaction of business is money.

Some light upon this question is to be had from the legal definition. of money for some of the purposes other than that of bills and notes.

In Moss v. Hancock $k^{42}$ it was held that the original owner of a rare $£_{5}$ gold piece that had been stolen could recover it, though it had been purchased innocently by a dealer in curiosities. The coin had not ceased to be legal tender. But it had been removed from the channels of trade, i. e., had ceased to be current and was taken by the dealer not as a representative of its nominal valure but as a thing possessing only intrinsic value. In the case of Miller $v$ : Race already quoted from, Lord Mansfield, treating a like question, said:

"The true-reason [why money cannot be followed into the hands of an innocent taker for value] is, upon account of the currency of it: it can not be recovered after it has passed in currency. . . but before money has passed in currency, an action may be brought for the money itself. - . It never shall be followed into the hands of a person who bona fide took it in the course of currency and in the way of his business. . . . A bank-note is constantly and universally, both at home and abroad, treated as money, as cash; and paid and received as cash; and it is necessary, for the purposes of commerce, that their currency should be established and secured." 43

A bequest of "moneys" covers not only coin but bank notes and other currency. It does not cover notes, bonds, mortgages and other securities. ${ }^{44}$

\footnotetext{
Miller v. Race (1758, K. B.) r Burrow, 452, 457.

- Nor does it exclude instruments such as national bank notes. They are promissory notes but they are also something more. They are currency, cash or money within Lord Mansfield's description.

"See Chapman v. Cole (1858, Mass.) I2 Gray, 141. An interesting account of the currency of the Isle of Man, which is in point, is found in Chitty, op. cit., 86, note 8. Here fall gold dust, pelts, and the like.

“ (1899) 2 Q. B. 3.

Miller v. Race, supra, 457-9. Brown v. Perea (1918) 176 N. Y. Supp. 215 is an important case in this connection.

"Mann v. Mann (1814, N. Y.) I Johns, Ch. 23I; Pohlman v. Pohlman, supra.
} 
The strictness with which criminal statutes and indictments are construed does not prevent larceny or embezzlement of "money" covering both what is legal tender and what is current." ${ }^{45}$ To have held otherwise when the penalty was death would be understandable but to-day it would not be good sense to make the result hinge on whether the accused happened to take a Silver Certificate or a United States note.

The authority of an agent to collect money extends to de facto as well as de jure money, but it does not include bills, checks, notes and the like. ${ }^{18}$

The power of the federal government to coin money and to borrow money on the credit of the United States is not limited to the coining and borrowing of legal tender.

There are a great many other situations where the word, money, has been given the broader definition ${ }^{47}$ and where the reasons for so doing are not so important as those in the case of commercial paper.

\section{INSTRUMENTS PAYABLE IN FOREIGN MONEY}

Before taking up the effect of the Negotiable Instruments Law, there remains to be considered under this head the effect of making an instrument payable in foreign money. To clear the ground for discussing this question it is necessary to distinguish some collateral matter.

The present question does not àrise if foreign money is used merely to designate the amount of value to be handed over in making payments provided the thing designated to be handed over is domestic money of the place of payment. ${ }^{48}$ Apart from possible uncertainty of amount, which is not considered here, an instrument so drawn is a bill or note. For the purpose in hand, an instrument reading, "I promise to pay in New York to $\mathrm{P}$ or order the value of one barrel of whiskey in the gold coin of the United States," is a promissory note just as it would be if, "one hundred pound sterling," were substituted for, "one barrel of whiskey." Nor does the question arise if the instrument expresses the sum to be paid in terms of the money of a foreign country and is silent as to the medium of payments. The fair meaning probably is that the instrument calls for money of the country where it is payable. Such an instrument is commercial.49

\footnotetext{
* Johnson v. State (19ra) I67 Ala. 82, 52 So. 652; State v. Finnegean (1905) I27 Iowa, 286, 103 N. W. I55; State v. Quackenbush (1906) 98 Minn. 515, 108 N. W. 953 ; cf. Block v. State (1876) 44 Tex. 620. See Territory v. Hale (1905) ${ }_{3}$ N. Mex. I8I; Hunt v. State (1904) 72 Ark. 24r, 79 S. W. 769.

${ }^{16}$ Mechem, Agency (2d ed. Ig03) 946.

"27 Cyc. 817-822. See Cary v. Courteney (r869) Io3 Mass. 316.

${ }^{43}$ Norton, op. cit., 67. See also Hebblethwaite v. Flint (1918) I85 App. Div. 249, 173 N. Y. Supp. 58r.

"King v. Hamilton (1882, C. C. Ore.) I2 Fed. 478; Black v. Ward (1873) 27 Mich. 19I; Hogue v. Williamson (1893) 85 Tex. 553, 22 S. W. 580 ; see Thomp-
} 
Although the designated medium of payment is money foreign to the place of payment, the commercial status of the instrument should not be held to be affected..$^{50}$ If the foreign money is current at the place of payment, as for example, United States money in parts of Mexico and Canada, the instrument should be held to be payable in money upon considerations already enumerated and for the reasons which follow. If the foreign money is not current in the place of payment, two positions are possible: (a) Such foreign money may be considered an ordinary commodity with the result that an instrument payable therein is non-commercial; (b) if the foreign money in question is that of one of the recognized nations of the world engaged in international trade, such money is a device of international trade and its status as such should be recognized ${ }^{51}$ with the result that an instrument payable therein is a commercial instrument. The first position is parochial and involves a failure to appreciate not only the international character of commercial law but also the growing needs of foreign trade.

Mr. Justice Field said:

"Undoubtedly it is the law that, to be negotiable, a bill, promissory note or check must be payable in money, or whatever is current as such by the law of the country where the instrument is drazen or payable." 52

\section{In Story on Bills it is said,}

"the Bill should be for the payment of money. . . . But, if it be payable in money, it is of no consequence in the currency or money of what country it is payable." ${ }^{33}$

son v. Sloan ( 1840, N. Y.) 23 Wend. 7I, per Cowan, J. Related questions not considered arise when the country of issue and the country of payment have money systems of identical denominations, but of different values. If the instrument is silent as to which is to be considered in fixing the amount to be paid, which is controlling? If there is inserted in the instrument, "payable in the money of the United States", does that stipulation relate to the amount to be paid, or to the medium of payment or to both?

${ }^{50}$ That such are commercial instruments: St. Stephen Branch Ry. v. Black (I870, New Brunswick) 2 Hann. 139. Dicta to this effect are found in Sanger v. Stimpson (181I) 8 Mass. 260; Black v. Ward, supra; Brown v. Perera (I918) I76 N. Y. Supp. 215; Hogue v. Williamson, supra; Third National Bank v. Crosby (1878) 43 U. C. Q. B. 58. Contra: Thompson v. Sloan (1840, N. Y.) 23 Wend. $7 \mathrm{I}$; Bettis v. Waller (I870) 30 U. C. R. 23 (in terms overruled in Third National Bank v. Crosby). Cf. Jones v. Fales (1808) 4 Mass. 245 and Young v. Adams (1810) 6 Mass. I82.

"The reasons for this position cannot be better stated than they are in Brown v. Perera, supra. The opinion of Leventritt, referee in the court below, is most excellent and shows a degree of understanding of the whole background of commercial law rarely to be found in the books since Lord Mansfield's time. Cf. Chapman v. Cole (1858, Mass.) I2 Gray, I4I.

${ }^{5}$ Bull $v$. Bank of Kasson, supra, II2.

ss Story, Bills of Exchange (2d ed. 1847) sec. 43. It has been suggested 
Chitty seems to go even farther when he says:

"But it is said, that it is not necessary that the money should be that current in the place of payment, or where the bill is drawn; it may be in money of any country whatever."

It is worthy of note that the Uniform Law adopted at the Hague provides in article 40 that the parties may expressly stipulate that the holder may demand payment in a specified foreign currency. Before rashly striking down all such instruments it might be prudent at least to inquire whether there is a distinction between an instrument drawn in New York and payable in New York in a medium of payment foreign to that place and an instrument drawn in London and payable in New York in a medium of payment which is money in London but not in New York. It would not be surprising to find that when the merchants of the Mediterranean city-states drew on the Lombards in London they not infrequently designated their own money as the medium of payment.

\section{EFFECT OF THE NEGOTIABLE INSTRUMENTS LAW}

The Negotiable Instruments Law does not touch the question whether instruments specifying foreign money as the payment medium are negotiable.

Under it, may a negotiable instrument be payable in de facto money as well as in legal tender? The act is ambiguous. Section I provides, "An instrument to be negotiable must contain an unconditional promise or order to pay a sum certain in money." By section I32 an acceptance "must not express that the drawee will perform his promise by any other means than the payment of money." In neither of these provisions is there a definition of "money." Section 6 provides," "The validity and negotiable character of an instrument are not affected by the fact that it . . . designates a particular kind of current money in which payment is to be made." 55 The main pur-

(Russel, op. cit., 55; Norton, op. cit., 62) that Story was here speaking of the designation of the amount to be paid as opposed to the medium of payment. But Story was aware of this distinction and he entertained no such localized notions of commercial law as is shown. by the authorities cited. He adds in secs. 44, 45, "The same rule prevails in both respects, in the French law. Pardessus has well observed, that . . . the nature and kind of money should be specified, when the payment is to be made in any other money than that of the place of payment. . . . Heineccius has added, that not only the sum of money should be expressed in the Bill, but also the kind of money, otherwise it will be taken to be the common currency of the country on which it is drawn." With Teidman, Commercial Paper (I889) sec. 29b, compare Teidman, Bills \& Notes (I898) sec. 22.

"Chitty, Bills of Exchange (IIth Am. ed. I849) *133.

ss The corresponding provision of the act as adopted in Illinois is "is payable in currency or current funds or designates." 
pose of this provision seems to be to codify the common-law rule as to deferred payments..$^{\text {se }}$ A definition of money is not the primary intent of this provision. If this be considered a definition of money by implication, and that is quite arguable, it adds confusion, if anything, for there is used, not the term currency or money, but the more uncertain combination, current money. Then again in section 125, defining material alteration, there appears, " . . . which changes . . . the medium or currency in which payment is to be made."

Only three cases involving this question have been deeided under the act. ${ }^{.7}$ The Supreme Court of Iowa has held ${ }^{58}$ that a check payable "in current funds". is not negotiable, following the previous holding in that state. ${ }^{59}$ There was no reference to the act. It has been held otherwise in Forest $v$. Trust Company ${ }^{80}$ as to a certificate of deposit with the same provision, this point not being discussed but the act being mentioned. In New York an agreement to pay " $\$ 2340$ currency" has been held negotiable under the Negotiable Instruments Law. ${ }^{\text {11 }}$

Though an amendment to the act may be necessary to secure a uniform rule that "money" for the purposes of the law of bills and notes is not limited to legal tender, ${ }^{62}$ it is arguable that the act is sufficiently ambiguous to permit, in view of the paramount purpose to secure uniformity, ${ }^{63}$ the abandoning of the legal tender definition and the consequent working out of a proper and uniform result under the act. What is more likely to happen first is that there will be an increasing number of courts, regardless of the act, revising their construction of the terms "currency," "current funds," etc., and holding them to be equivalent to legal tender, as the Supreme Court of Indiana has done recently. ${ }^{84}$ This, however, would not save an instrument expressly payable in gold or silver certificates, national bank notes

"See infra.

"Burritt v. Lamny (I9I6) 90 Conn. 491, 97 Atl. 756, merely holds that a tender of de jacto money is a valid tender if not objected to on the ground that the money tendered is not legal tender.

${ }^{83}$ Dille v. White (I906) I32 Iowa, 327, I09 N. W. gog.

"Huse v. Hamblin (187a) 29 Iowa, 5ar and cases in note 24, supra.

(Ig09, C. C. E. D. Pa.) I74 Fed. 345. This case follows the prior rule in the federal courts. Bull v. Bank of Casson, supra.

"Merchants National Bank v. Saǹta Maria Sugar Co. (1914) 162 App. Div. 248,147 N. Y. Supp. 498. This is in accord with the New York law prior to the act. Frank v. Wessels (1876) 64 N. Y. I55.

${ }^{02}$ Professor Brannon suggests in (I9I3) 26 HARV. L. REV., 493, an amendment for this purpose. The amendment suggested does not include instruments payable in foreign money unless such money is lawfully and actually circulating at par with legal tender at the time and place of payment. All such instruments should be included. The word "lawfully" as here used is ambiguous, and it should not be forgotten that some circulating media not legal tender have passed at a premium and may do so again.

* For cases on this see Brannon, Negotiable Instruments Law (2d ed. IgII) I.

* Millikan v. Security Trust Co. (IgI8, Ind.) II8 N. E. 556. 
or Federal Reserve notes which constitute by far the greater part of the money in actual use. They are all lawfully circulating. It is desirable that the law should conform to the national monetary policy which they represent. But what is more serious, dealing with the matter by construction rather than. by abandonment of the notion that legal tender is definitive of money results in business men being unable to make instruments negotiable and at the same time to protect themselves against demand for payment in the kinds of money that are but a fraction of the available currency of the nation.

\section{SPECIFYING A PARTICULAR KIND OF MONEY}

Granted that the thing in which the instrument is payable is money, such an instrument does not lose its commercial character if it specifies a particular kind of money in which payment is to be made. ${ }^{85}$ This rule is codified in section 6 subdivision 5 of the Negotiable Instruments Law. ${ }^{60}$ The business background out of which this rule emerges is that, while over relative long periods of time the purchasing power of all kinds of money (however money may be defined) varies, in addition to this variation, the value of some kinds of money in relation to other kinds sometimes fluctuates. For the repayment of his debt a man advancing credit may naturally desire to choose a particular kind of money which he thinks likely to undergo a minimum of variation in value of the second sort so that, to this extent, at least, he may guard against receiving in return less value than he has advanced. And the debtor, too, may desire, as far as possible to guard against his having to return a greater value than he has received. A rule of law making this possible facilitates long time credit transactions particularly and involves an interest which the law should and does sanction. ${ }^{67}$ But obviously the reasons back of this rule are not

\footnotetext{
${ }^{2}$ Chrysler v. Renois (1870) 43 N. Y. 209, seems to be the only case in which the question is alluded to by the court. There are many cases which treat such instrument as commercial, the point not being considered, e. g., Trebilcock $v$. Wilson, supra; Wood v. Bullen (1863, Mass.) 6 Allen 516; Phillips v. Dugan (1871) 21 Oh. St. 466; Sinith v. McKinley (1871) 22 Oh. St. 200; Hogue v. Williamson, supra; Strickland v. Holbrooke (I888) 75 Calif. 642; Churchman v. Martin ( 1877 , Ind.) 4 CENT. L. J. 343. In point would be cases involving instruments payable in paper currency in jurisdictions holding money to mean de facto money. Cf. Frank v. Wessel, supra; Kelley v. Ferguson (1873, N. Y.) 46 How. Prac. 4Ir. An instrument payable in United States gold coin is a note within section 3088 of the Calif. Civ. Code. Eastman v. Sunset Park Land Co. (1917) 35 Calif. App. 628, 170 Pac. 642. An entirely separate question, considered in note 67 , infra, is whether the law gives effect to such stipulations.

"No case under the statute has been found. Few, if any, questions concerning this provision are likely to arise.

"The leading case on this question is Bronson v. Rodes ( 1868, U. S.) 7 Wall. 229. Other cases are collected in 6 Rose's Notes (Rev. ed.) 583-587. Prior to Bronson v. Rodes there was a division in judicial opinion on the question as to the enforcibility. of contracts to make payment in gold or silver. $29 \mathrm{~L}$. R. A.
} 
based upon any notion that the attribute of being legal tender is the distinguishing characteristic of money at all times and places and for all purposes. Here the attribute in the foreground is its aspect as a standard of value for deferred payments. The law recognizes this social utility which money has and, recognizing, too, that it does not perform this function perfectly, sanctions this corrective device.

If financial history showed that the kinds of money commonly given by law the attribute of legal tender typically were least subject to the variation in value in question, the cases involving the rule here discussed would lend support to the view that, for the purposes of bills and notes, money means legal tender. But such is not the fact of experience. ${ }^{88}$ The most obvious and frequent means adopted by legislators to check the declining value of a particular kind of money has been to attempt to compel. acceptance of it by making it legal tender.

But more may be said. If the purpose is the standardization of deferred payments and the choice of means for so doing is limited to defining money either as that which is legal tender or as that which is in fact current, the kinds of money, which in the long run are likely to be subject to the least change in future value will, in the main, be as nearly identical with those which are generally acceptablei. e., which pass current now-as with the kinds which may happen to be legal tender.

If there are considered only the business situations giving rise to the rule that a bill or note may be made payable in a particular kind of money, it would be desirable to define money so as to limit it to the kinds the values of which are least likely to change in relation to the values of other kinds. But another interest must be considered, viz., that there shall be admitted to the category of commercial paper all instruments payable in a medium approximating universal acceptability. If, in rare cases, the two conflict, the former should give way because of their relative commercial importance and of the sufficiency of the present rule to take care of the occasional cases of conflict.

512, note collecting cases. See Echols v. Grattan (187I) $42 \mathrm{Ga} .547$, and Caldwell v. Craig ( $1872, \mathrm{Va}$ ) 22 Gratt. 340 , on the difficulties of construction often found in cases of this kind. The opinion of Chief Justice Chase in Browson v. Rodes is instructive especially when compared with such reasoning as was found in cases like Wood v. Bullen, supra.

${ }^{*}$ United States $v$. American Gold Coin (I868) Fed. Cas., No. I4,439; For other examples see the financial history reflected in the cases collected in 29 L. R. A. 512 note, and in Dorrance v. Stewart (1794, Pa.) I Yeates, 349. 